Creative Commons User License: CC BY-NC-ND

Abstracted by: EBSCOhost, Electronic Journals Service (EJS),

Google Scholar, Journal Seek, Scientific Commons,

Food and Agricultural Organization (FAO), CABI and Scopus

http://eoi.citefactor.org/10.11226/v24i4
Journal of Agricultural Extension

Vol. 24 (4) October, 2020

ISSN(e): 24086851; ISSN(Print); 1119944X

http://journal.aesonnigeria.org

http://www.ajol.info/index.php/iae

Email: editorinchief@aesonnigeria.org

\title{
Farmers' Perceptions of Organic Agriculture in Southern Saudi Arabia
}

https://dx.doi.org/10.4314/jae.v24i4.3

\author{
Bader, Alhafi Alotaibi \\ Department of Agricultural Extension and Rural Society, \\ King Saud University, Riyadh 11451, Saudi Arabia \\ Email: balhafi@ksu.edu.sa, +966504240201
}

\begin{abstract}
The study assessed farmers' perception of organic agriculture and level of knowledge regarding organic farming practices. The study involved a random sample of farmers from the governorate. The farmers' perceptions regarding organic agriculture were slightly positive, although they had a low level of knowledge about organic farming practices. More than half of the farmers had insufficient knowledge about practicing organic farming. Farmers who practiced organic farming had networks with other farmers, sourced of information, and had training in organic agriculture were more likely to have greater perception of the importance of organic agriculture. Similarly, farmers educated beyond high school and younger than 40 years were more positive about organic farming than other farmers. Understanding farmers' perceptions of the subject will prepare extension agents to develop better programmes in organic agriculture practices. Extension agents and policymakers should concentrate on these factors in developing training programmes for farmers.
\end{abstract}

Key words: organic agriculture, farmers' perceptions, extension, Saudi Arabia.

\section{Introduction}

In the Kingdom of Saudi Arabia (KSA), the agriculture sector has played a vital role in food security, economic diversity and the alleviation of poverty. The government has endeavored to achieve food security by devising water distribution approaches among farmers and encouraging adoption of environmentally friendly agricultural practices. Moreover, Saudi Arabia has expanded investment in and collaboration with countries that maintain high agricultural production levels to increase production while simultaneously saving water (Alotaibi, 2018). In 2019, the agriculture sector in Saudi Arabia represented 2.33\% of the country's GDP, with a total $\$ 16.37$ billion USD.

Additionally, the agricultural sector has witnessed several developments for the past three years, the most important being the National Agriculture Strategy. The strategy has several programs such as the Agricultural Rural Development program and the agricultural subsidy program. These programs are designed to improve economic and social conditions for Saudi Arabian citizens via the establishment of multiple agricultural projects. These projects use agricultural techniques that have transformed traditional agricultural production methods to become more developed 
Creative Commons User License: CC BY-NC-ND

Abstracted by: EBSCOhost, Electronic Journals Service (EJS), Google Scholar, Journal Seek, Scientific Commons,

Food and Agricultural Organization (FAO), CABI and Scopus
Journal of Agricultural Extension

Vol. 24 (4) October, 2020

ISSN(e): 24086851; ISSN(Print); 1119944X

http://journal.aesonnigeria.org

http://www.ajol.info/index.php/jae

Email: editorinchief@aesonnigeria.org

and to support rural community and farm well-being (Ministry of Environment, Water, \& Agriculture, 2019).

However, some problems have accompanied the incorporation and adoption of new agricultural methods in KSA. For example, there have been negative impacts on the environment and natural resources as a result of the intensification of agricultural production. Reduced soil fertility; decreased water quality, and soil erosion have resulted due to intensified production methods and the heavy use of chemical fertilizers and pesticides. These problems were caused by the need to overcome diseases and pests that did not exist previously but emerged due to an imbalance in the natural ecosystem. As a result, Saudi Arabia faces life-threatening issues, especially when pesticides move through the soil, water, and air and contribute to reduced biodiversity and pollution. Therefore, traditional agricultural production methods may conflict with optimal and sustainable utilization of natural resources; consequently, there is a need to consider organic farming as a means to sustainable agriculture in Saudi Arabia (Ramadan, Abdel-Hamid, Altorgoman, AlGaramah, Alawi, Shati, et al, 2020 \& Ministry of Environment, Water, and Agriculture, 2019).

In addition, population and economic growth in Saudi Arabia over the past three decades has increased the growth rate in sectors such as oil, agriculture, industry, and tourism. No attention has been paid to environmental deterioration. This is reflected in the decline in the health of humans, and it threatens natural resources and sustainability (Ministry of Environment, Water, \& Agriculture, 2018). To overcome these challenges, the government developed 11 strategic programs to enhance food security; one of them is designed to achieve sustainability and increase the growth of organic agriculture $(\mathrm{OA})$.

The National Environment Strategy (Ministry of Environment, Water, \& Agriculture, 2018) promoted organic farming practices and regulated the use of fertilizer and pesticides as best practices for sustainable agriculture. Saudi Arabian agricultural policy emphasizes the diffusion and implementation of OA practices among farmers to achieve a balance between agricultural production and the preservation of natural resources. The National Vision 2030 for Agriculture introduced OA development. The initiative focuses on agricultural practices by supporting the development of the $O A$ sector and defining specifications and product guarantees.

The Ministry of Agriculture instituted new regulations for the country's OA system after Royal Decree No. M/55 was passed on 9/16/1435 H 7 July 2014. The Ministry defined the OA system as a method of agricultural production of both plants and animals that depends on using natural materials to produce food without using fertilizer, chemicals, hormones, genetically modified organisms, and any materials derived from them. The government's definition minimizes the amount of external inputs used to maximize agricultural production. In 2016, Royal Decree No. A/133, 
Creative Commons User License: CC BY-NC-ND

Abstracted by: EBSCOhost, Electronic Journals Service (EJS), Google Scholar, Journal Seek, Scientific Commons,

Food and Agricultural Organization (FAO), CABI and Scopus

http://eoi.citefactor.org/10.11226/v24i4
Journal of Agricultural Extension

Vol. 24 (4) October, 2020

ISSN(e): 24086851; ISSN(Print); 1119944X

http://journal.aesonnigeria.org

http://www.ajol.info/index.php/iae

Email: editorinchief@aesonnigeria.org

dated May 7, 2016, changed the name of the Ministry of Agriculture to the Ministry of Environment, Water, and Agriculture (MEWA).

The OA sector in Saudi Arabia has been growing fast. The total amount of organic production in 2015 was 44.6 thousand tons; however, organic production increased by $18.4 \%$ in 2019 to 52.6 thousand tons. The total area in organic production is $2,630.49$ hectares, with around 664.75 hectares under transformation. By comparison, however, in Jazan Region there are only 2.4 hectares in organic production, with 2.3 hectares under transformation (MEWA, 2019). The Ministry of Environment, Water, and Agriculture has allocated 750 million SAR to support both $\mathrm{OA}$ and farmers converting to OA. Understanding farmers' perspectives on OA will help extension agents develop an organic farming training programme and increase the practice of $O A$; thus, a lack of knowledge on the part of farmers can be a barrier to adopting OA (Alotaibi, Yoder, Brennan, \& Kassem, 2019).

The purpose of this study was to assess perception of farmers in Jazan Region regarding $O A$. The study first examines farmers' perceptions and knowledge regarding $O A$. It then determines if farmers' perceptions and knowledge towards $O A$ differs across the demographic variables.

\section{Methodology}

Jazan Region is located in the southwest of Saudi Arabia along the Red Sea. The region has approximately $1,1671 \mathrm{~km}^{2}$ and includes $300 \mathrm{~km}$ of the Southern Red Sea coastline. The region represents only $0.7 \%$ of the total area of Saudi Arabia; however, it is one of the richest agricultural areas in the country. Administratively, Jazan Region includes 16 governorates and lies between $42.33^{\circ} \mathrm{E}$ and $16.53^{\circ} \mathrm{N}$. Jazan is the centre of mango fruit production in Saudi Arabia, with around 750,000 trees producing 35,000 tons annually. The other crops in the region include sesame, millet, corn, okra, and tomatoes. Fresh water resources include ground water, rains, and flash floods (Alotaibi, Kassem, Nayak, \& Muddassir, 2020).

The Abu Arish governorate, located in central Jazan, was randomly selected for data collection; this governorate has the highest population in the region. The target population consisted of 800 farmers in the districts selected. Farmers were listed based on their addresses at the extension agents' office in the region. Two hundred farmers were invited to participate in the study, and 164 subjects completed the interviews, resulting in a response rate of $82 \%$. Prior to data collection, farmers were duly informed and assured that the information gathered was for academic purposes only and that their participation was voluntary (McCusker \& Gunaydin, 2015). A survey instrument was developed and validated by a group of experts, including extension agents. From January to March 2019, data were collected by administering an Arabic version of the instrument, which employed the face-to-face interview approach. 
Creative Commons User License: CC BY-NC-ND

Abstracted by: EBSCOhost, Electronic Journals Service (EJS), Google Scholar, Journal Seek, Scientific Commons,

Food and Agricultural Organization (FAO), CABI and Scopus
Journal of Agricultural Extension

Vol. 24 (4) October, 2020

ISSN(e): 24086851; ISSN(Print); 1119944X

http://journal.aesonnigeria.org

http://www.ajol.info/index.php/iae

Email: editorinchief@aesonnigeria.org

Farmers were asked about their characteristics, perceptions, and knowledge regarding OA. Data collection was completed by administering a three-section instrument. The first part contained socioeconomic questions, including age, education, farming experience, organic farming experience, training in OA types of farming activities, access to extension services, membership in agricultural cooperatives, farm size, sources of information about $O A$, desire to practice $O A$, and types of farmers.

The second part of the survey addressed farmers' perceptions regarding OA. The respondents were asked to rank each item on a 5-point Likert scale: $(1=$ strongly disagree, 2 = disagree, 3 = neither, 4 =agree, 5 = strongly agree). The researcher used the following criteria to qualitatively describe and interpret the results: 1.00 $1.50=$ strongly disagree, $1.51-2.50=$ disagree, $2.51-3.50=$ undecided, $3.51-4.50=$ agree, and 4.51-5.00 = strongly agree. To determine farmers' perceptions of OA, the 10 survey items that asked farmers to consider OA were summated. The scale ranged from 10 (farmers disagreed with the item) to 50 (farmers agreed with the item).

The third section assessed farmers' knowledge of how to grow organic crops. The items were developed by Marsh, Zoumenou, Cotton, \& Hashem (2017). Farmers were asked to rate their level of knowledge regarding OA practices by using a threepoint scale (1-3), where 1 was no knowledge, 2 was medium knowledge, and 3 was high knowledge. The researcher used the following criteria to qualitatively describe and interpret the results: $1.00-1.50=$ no knowledge, $1.51-2.50=$ Some or medium knowledge, and 2.51-3 = high knowledge. The questionnaire was developed in the English language and then translated into Arabic.

Data were analysed using the IBM-SPSS Statistics, version 26, to determine percentages, means, and standard deviations. A $t$-test was used to find out the differences among farmer groups and to examine the significance of farmers' experiences in $O A$, training in $O A$, types of farmers, desire to practice $O A$, availability of sources of information about $O A$, and communication with other farmers regarding OA. Cohen's $d$ was used to determine the mean difference between two groups.

The following dependent variables were used: 1) individual items regarding farmers' perceptions toward $\mathrm{OA}$; and 2) individual items regarding farmers' interest in training in OA. For the independent $t$-test, the statistical assumption regarding homogeneity of variance was assessed. If there was unequal variance, the adjusted (correction factor for df) unequal variance $t$-test was used. One-way analysis of variance (ANOVA) was used to examine the significant differences in means among age groups and educational levels and also to determine if any statistically significant differences existed between farmers' perceptions and their demographic characteristics. The ANOVA statistical assumptions of equal variance (Levene's test) 
Creative Commons User License: CC BY-NC-ND

Abstracted by: EBSCOhost, Electronic Journals Service (EJS), Google Scholar, Journal Seek, Scientific Commons,

Food and Agricultural Organization (FAO), CABI and Scopus
Journal of Agricultural Extension

Vol. 24 (4) October, 2020

ISSN(e): 24086851; ISSN(Print); 1119944X

http://journal.aesonnigeria.org

http://www.ajol.info/index.php/iae

Email: editorinchief@aesonnigeria.org

and normality of the dependent variable across the levels of the independent variable were checked. The Games-Howell post hoc test was used when the equal variance assumption was not met, and a post hoc follow-up test was required. The Scheffe post hoc test was used when the equal variance assumption was met and a post hoc test was required. The reliability for the farmers' perceptions scale was high $(r=0.84)$.

\section{Results and Discussion}

\section{Farmers' Backgrounds.}

Table 1 shows that approximately $72 \%$ of farmers had more than 11 years' experience in agriculture, while about $28 \%$ of farmers had less than 10 years' experience in the agricultural sector. Most farmers (64\%) reported that they cultivated vegetables; the average amount of experience in agriculture was 14.34 years. In Saudi Arabia farming is dominated by males and foreign laborers. The majority of farmers $(61.6 \%)$ had no experience in $\mathrm{OA}$, while $38.4 \%$ had experience in $\mathrm{OA}$ : the average experience in $\mathrm{OA}$ was 1.38 years. The majority of farmers $(74.6 \%)$ had no training in OA, and only $25.4 \%$ had training. The average length of time spent in training was low than one time. Table 1 reveals that more than $50 \%$ of the farmers did not have a high school education; only $17 \%$ graduated high school. This implies, however, that the farmers are able to read and understand new agricultural production paradigms such as OA. There were a few farmers with a Bachelor's degree. Approximately $55.5 \%$ of the farmers wanted to practice OA, while $44.5 \%$ did not want to practice it. More than half of the farmers (54\%) communicated with other groups of farmers about OA. Most of the farmers (82.3\%) were conventional farmers, and only $17.7 \%$ were organic farmers. These results were in line with previous studies that indicated all farmers agreed that organic farming contributed to better for environmental problems. However, organic farmers believed that organic farming is more profitable than conventional agriculture (Berg, Maneas, \& Salguero Engström, 2018). In addition, the results about extension services, experience, crops, and education level were in the line with Alotaibi, Kassem, Nayak, R\& Muddassir ,2020) 
Creative Commons User License: CC BY-NC-ND

Abstracted by: EBSCOhost, Electronic Journals Service (EJS), Google Scholar, Journal Seek, Scientific Commons,

Food and Agricultural Organization (FAO), CABI and Scopus
Journal of Agricultural Extension

Vol. 24 (4) October, 2020

ISSN(e): 24086851; ISSN(Print); 1119944X

http://journal.aesonnigeria.org

http://www.aiol.info/index.php/iae

Email: editorinchief@aesonnigeria.org

\section{Table 1: Farmers' background.} Farmers' Demographics

Experience in agriculture

$\begin{array}{cc}\leq 5 \text { yrs. } & 10.4 \\ 6-10 & 17.7 \\ 11-15 & 25.6 \\ \geq 16 \text { yrs. } & 46.4 \\ \text { Mean }=14.34 ; \mathrm{SD}=8.42 ; \text { Range }=49 ; \text { Low }=1 ; \text { High }=50\end{array}$

Yes, experience in OA

Mean = 1.38; SD = .48; Range $=22 ;$ Low $=0 ;$ High $=22$

Training in organic agriculture

$$
\begin{aligned}
& \text { Yes, training } \\
& \text { Mean = .46; } \mathrm{SD}=1.01 ; \text { Range }=6 ; \text { Low }=0 ; \mathrm{High}=6
\end{aligned}
$$

Extension services

Yes, extension services

Education Level

Less than high school

High School

Diploma

Bachelor

\section{Crops $^{*}$}

Vegetable

Fruits

Other corps

Source of Information about OA

$$
\text { Yes }
$$

Communicate with Other Farmers about OA

Yes

50.6

17.1

15.9

16.5

64.0

35.6

30.4

47.6

53.7

Are you an organic farmer?

Yes

${ }^{\star}$ Multipole response

\section{Farmers' Perceptions of Organic Agriculture}

Farmers in Jazan Region had a slightly positive perception of OA. Farmers indicated that the actual scores ranged from a low of 20 to a high of 50, with a mean of 36.46 and a standard deviation of 5.82. The averaged mean of the item was 3.64, and, therefore, the results indicated that overall, farmers had a slightly positive perception of OA. This result is in line with Oyedele, Wole-Alo, Owolabi, and Okunlola, (2018) and Bouttes, Darnhofer\& Martin, G. (2019) who found that farmers had a positive perception regarding OA but had not yet adopted an organic system of farming. Table 2 shows that farmers expressed high agreement with five statements about their perceptions regarding $\mathrm{OA}$, whereas the other five items received moderate 
Creative Commons User License: CC BY-NC-ND

Abstracted by: EBSCOhost, Electronic Journals Service (EJS), Google Scholar, Journal Seek, Scientific Commons,

Food and Agricultural Organization (FAO), CABI and Scopus

http://eoi.citefactor.org/10.11226/v24i4
Journal of Agricultural Extension

Vol. 24 (4) October, 2020

ISSN(e): 24086851; ISSN(Print); 1119944X

http://journal.aesonnigeria.org

http://www.ajol.info/index.php/iae

Email: editorinchief@aesonnigeria.org

agreement from the farmers. The main areas with high agreement included: Practice of organic agriculture gives an opportunity to build skills $(\bar{x} 4.11 ;$ SD 0.89$)$; the

absence of agricultural products from chemical fertilizers is safe for humans and animals ( $\bar{x} 4.08$; SD 0.98$)$; the change to organic agriculture is a new challenge $(\bar{x}$

4.08; SD 0.84), and organic agriculture is generally better for the environment $(\bar{x}$

4.00; SD 0.81). In addition, these results are similar to a previous study by Janjhua, Chaudhary, Mehta, and Kumar (2019). This finding - which indicated farmers had positive perceptions-is essential knowledge for extension agents, who must understand farmers' perceptions in order to develop an effective extension program. In general, farmers had positive perceptions of $O A$, and the application of this finding is that farmers in Jazan Region will adopt OA when they receive adequate training and sufficient information regarding $O A$.

\section{Table 2: Farmers' perceptions of organic agriculture}

\begin{tabular}{lcc}
\hline \multicolumn{1}{c}{ Item } & Mean & SD \\
\hline $\begin{array}{l}\text { Practice of organic agriculture gives an opportunity to build } \\
\text { skills. }\end{array}$ & 4.11 & 0.89 \\
The absence of agricultural products from chemical fertilizers & 4.08 & 0.98 \\
is safe for humans and animals. & 4.08 & 0.84 \\
The change to organic agriculture is a new challenge. & 4.00 & 0.81 \\
Organic agriculture is generally better for the environment. & 3.90 & 0.86 \\
$\begin{array}{l}\text { Organic agriculture is desirable among local farmers. } \\
\text { Organic agriculture is the best way to ensure sustainable }\end{array}$ & 3.77 & 0.78 \\
agriculture. & 3.54 & 0.87 \\
Organic agriculture is more profitable than traditional & & 0.78 \\
agriculture. & 3.40 & 0.95 \\
Profits from organic products are high. & 3.35 & 1.15 \\
Organic agriculture standards are complex, and it is not easy \\
to practice it. \\
$\begin{array}{l}\text { In organic agriculture, pests, weeds, and diseases cannot be } \\
\text { controlled. }\end{array}$
\end{tabular}

Summated Mean $=36.46 ; \mathrm{SD}=5.82 ;$ Range $=30 ;$ Low $=20 ;$ and High $=50 ;$ Item Mean $=3.64$

\section{Farmers' Knowledge of Organic Practices}

Table 3 shows that more than half of the farmers had no knowledge about the cost of production, practices, and certification. Few farmers had slightly average knowledge about: quality of organic crops $(\bar{x}=1.54)$, and marketing for organic product $(\bar{x}$

$=1.52$ ). Fewer than the average number of farmers had at least some knowledge.

Overall, farmers' knowledge about organic practices was less than average for each 
Creative Commons User License: CC BY-NC-ND

Abstracted by: EBSCOhost, Electronic Journals Service (EJS), Google Scholar, Journal Seek, Scientific Commons,

Food and Agricultural Organization (FAO), CABI and Scopus

http://eoi.citefactor.org/10.11226/v24i4
Journal of Agricultural Extension

Vol. 24 (4) October, 2020

ISSN(e): 24086851; ISSN(Print); 1119944X

http://journal.aesonnigeria.org

http://www.aiol.info/index.php/iae

Email: editorinchief@aesonnigeria.org

of the categories assessed as shown in Table 3. Therefore, knowledge must be increased among farmers. The results indicated that there is a need for extension education programs to help interested farmers adopt and practice OA. These results are in line with previous studies for organic extension education, such as Marsh et al. (2017); Thinley \& Tashi (2020) and, Altarawneh (2016).

Table 3: Level of knowledge of organic growing practices

\begin{tabular}{lcc}
\hline \multicolumn{1}{c}{ Item } & Mean & SD \\
\hline Cost of growing organic crops & 1.49 & .57 \\
Market for organic products & 1.52 & .62 \\
Practice of organic agriculture and safety & 1.49 & .58 \\
Quality of organic products & 1.54 & .67 \\
Obtaining organic certification & 1.45 & .621
\end{tabular}

Summated Mean = 7.46; SD = 2.8; Range $=10 ;$ Low $=5 ;$ and High $=15 ;$ Item Mean $=1.49$

\section{Farmers' Perceptions of Organic Agriculture According to professional backgrounds.}

The results show that farmers who practiced organic farming had significantly higher OA perceptions than farmers who did not practice organic farming $(t=5.10, p \leq .001$,

Cohen's $d=1.20$ ), (Table 4). There was a means difference of 5.77 , and its power as determined by the effect size was 1.20 , which was considered a large effect size. This result supports that of Wayman, Kucek, Mirsky, Ackroyd, Cordeau \& Ryan (2017) who found that organic farmers and conventional farmers differ in their perspectives on terms of why the practice organic farming and also organic farmers believed OA is important role in agricultural sustainability.

Skaalsveen, Ingram\& Urquhart, (2020) found that networks with other farmers largely effect farmers learning and decision making in their farm. Their results support our finding which indicated that farmers who communicated with other farmers about $O A$ had significantly higher perceptions regarding $O A$ than those who did not communicate with other farmers about OA $(t=10.5, p \leq .001$, Cohen's $d$

$=1.73$ ). The difference in means was 7.66; its power as determined by the effect size of 1.73 is considered a large effect size.

There was also a significant difference in the available sources of information regarding OA. Farmers who had sources of information had better perceptions about OA than those who did not have sources of information $(t=8.10, p \leq .001$, Cohen's $d$

$=1.31$ ). The difference in means was 6.32, and its power as determined by the effect size was 1.31, which is considered a large effect size. Farmers with training in $\mathrm{OA}$ had significantly higher OA perceptions than those with no training in OA $(t=2.38, p$ 
Creative Commons User License: CC BY-NC-ND

Abstracted by: EBSCOhost, Electronic Journals Service (EJS), Google Scholar, Journal Seek, Scientific Commons,

Food and Agricultural Organization (FAO), CABI and Scopus
Journal of Agricultural Extension

Vol. 24 (4) October, 2020

ISSN(e): 24086851; ISSN(Print); 1119944X

http://journal.aesonnigeria.org http://www.aiol.info/index.php/iae

Email: editorinchief@aesonnigeria.org

$\leq .001$, Cohen's $d=0.53$ ). The difference in means was 2.77 , and its power, as determined by the effect size, was 0.53 . This effect size is considered a medium effect. This result is in line with the findings of Singha, Deka Bidyut, Bordoloi \& Parisa, (2020) in India, that participation in organic farming-related training was significantly associated with the perception of the benefits of OA. It was hypothesized that farmers who had no extension services would have a different perception of $O A$ than those who had extension services, but no significant differences were found in the extension services.

Both groups equally viewed $O A$ as positive. This result was not in line with previous studies that confirmed that growers who received or had contact with extension highly perceived the benefits of OA compared to nonorganic growers (Janjhua et al., 2019; Pinthukas, 2015; Rana, Hasan, Alam, \& Islam, 2017; Usman, Abdullahi, Qasimu, \& Adamu, 2016).

Table 4: Differences between farmers' perceptions on source of information, communication with other farmers, and extension services

\begin{tabular}{|c|c|c|c|c|}
\hline Variable & Mean & $S D$ & $T$ & Cohen's d \\
\hline Organic farmer & 41.14 & 3.63 & 5.10 & 1.20 \\
\hline Non- Organic farmer & 35.37 & 5.71 & & \\
\hline $\begin{array}{c}\text { Communicate with Other } \\
\text { Farmers about OA }\end{array}$ & 40.24 & 3.61 & 10.5 & 1.73 \\
\hline $\begin{array}{l}\text { Does not Communicate with } \\
\text { Other Farmers about OA }\end{array}$ & 32.58 & 5.08 & & \\
\hline $\begin{array}{c}\text { Source of Information about } \\
\text { OA }\end{array}$ & 39.96 & 3.79 & 8.10 & 1.31 \\
\hline $\begin{array}{c}\text { No Source of Information } \\
\text { about OA }\end{array}$ & 33.64 & 5.65 & & \\
\hline Training in $O A$ & 39.56 & 4.62 & 2.38 & 0.53 \\
\hline No Training in $\mathrm{OA}$ & 36.79 & 5.74 & & \\
\hline Extension Services & 36.15 & 7.16 & .365 & -0.05 \\
\hline No Extension Services & 36.51 & 4.82 & & \\
\hline
\end{tabular}

\section{Farmers' Perceptions of Organic Agriculture by Demographic Characteristics.}

There was a significant difference in means of the farmers' perceptions regarding $O A$ at the education level. A significant difference in means $(d f=3 / 144 ; F=2.63, p \leq$ 0.05 ), existed between farmers with a diploma and farmers who had not completed high school. The Games-Howell post hoc test indicated that farmers with high 
Creative Commons User License: CC BY-NC-ND

Abstracted by: EBSCOhost, Electronic Journals Service (EJS), Google Scholar, Journal Seek, Scientific Commons,

Food and Agricultural Organization (FAO), CABI and Scopus
Journal of Agricultural Extension

Vol. 24 (4) October, 2020

ISSN(e): 24086851; ISSN(Print); 1119944X

http://journal.aesonnigeria.org

http://www.aiol.info/index.php/iae

Email: editorinchief@aesonnigeria.org

http://eoi.citefactor.org/10.11226/v24i4

school diplomas ( $\bar{x}=38.13)$ had a significantly higher mean compared with farmers

who did not have a high school education. This difference in the mean would be considered a low effect (Partial Eta Squared $=.052$ ). This result is consistent with the study of Oyedele et al. (2018), who argued that the perceptions of Nigerian farmers were significantly associated with their education.

A significant difference in means was also found in the farmers' age category. A significant difference in means $(d f=3 / 144 ; F=10.58, p<0.05)$, determined by the Scheffe post hoc analysis test, existed between farmers whose ages were between 29-39 years and those who were older than 60 . The post hoc test indicated that farmers who were under 40 ( $\bar{x}=39.29)$ had a significantly higher mean, compared

with farmers older than 40. A significant difference in means was also found between those between 40 and 49 years of age and those who were older than 60 . The findings align with those of previous studies (Thinley \& Tashi (2020; Adamu, Oose, \& Bello, 2015; Janjhua et al., 2019 and Usman et al., 2016).

Table 5: Frarmers' perceptions of organic agriculture by education level and age

\begin{tabular}{llll}
\hline Variable and Level & Mean & SD & $\boldsymbol{F}$ \\
\hline Education level & & & \\
Less than high school & 35.20 & 6.38 & $2.63^{*}$ \\
High school & 37.12 & 5.57 & \\
Diploma & 38.13 & 4.48 & \\
Bachelor & 38.08 & 4.68 & $10.58^{*}$ \\
Age & & & \\
29-39 yrs. & 39.29 & 4.69 & \\
$40-49$ yrs. & 36.06 & 5.00 & \\
$50-59$ yrs. & 36.03 & 5.57 & \\
$\geq 60$ yrs. & 29.00 & 7.00 &
\end{tabular}

\section{Conclusions and Recommendations}

Farmers had a positive perception regarding organic agriculture. Age, education level, training in OA, source of information about OA, network with other farmers about $O A$ influenced farmers' perceptions. Extension agents should emphasis training of policy makers and farmers on organic farming. The training should include how to change to $O A$, marketing organic products, organic certification, and the practice of OA. Government policy should aim at providing incentives for organic farming

Acknowledgments: The author is grateful to the Deanship of Scientific Research and RSSU at the King Saud University for their technical support. 
Creative Commons User License: CC BY-NC-ND

Abstracted by: EBSCOhost, Electronic Journals Service (EJS), Google Scholar, Journal Seek, Scientific Commons,

Food and Agricultural Organization (FAO), CABI and Scopus

http://eoi.citefactor.org/10.11226/v24i4
Journal of Agricultural Extension

Vol. 24 (4) October, 2020

ISSN(e): 24086851; ISSN(Print); 1119944X

http://journal.aesonnigeria.org

http://www.aiol.info/index.php/iae

Email: editorinchief@aesonnigeria.org

\section{References}

Adamu, C. O., Oose, M. O., \& Bello, N. A. (2015). Farmers' perception towards organicbased vegetable production in Ilaro Agricultural Zone, Ogun State, Nigeria. International Journal of Applied Agriculture and Apiculture Research, 11(1-2), 115-122.

Alotaibi, B. A., Yoder, E., Brennan, M. A., \& Kassem, H. S. (2019). Training needs of extension agents' regarding organic agriculture in Saudi Arabia. Evaluation Program Planning, 77, 101711.

Alotaibi, B. M. (2018 a). Riyadh extension agents' perceptions regarding organic agriculture and implications for training (Order No. 10903616). Available from ProQuest Dissertations \& Theses Global. (2077229103).

Alotaibi, B. A.; Kassem, H. S.; Nayak, R. K.; Muddassir, M. (2020). Farmers' beliefs and concerns about climate change: An assessment from Southern Saudi Arabia. Agriculture, 10, 253.

Altarawneh, M. (2016). Determine the barriers of organic agriculture implementation in Jordan. Bulgarian Journal of Agricultural Science, 22(1), 10-15.

Bouttes, M., Darnhofer, I., \& Martin, G. (2019). Converting to organic farming as a way to enhance adaptive capacity. Organic Agriculture, 9(2), 235-247

Berg, H., Maneas, G., \& Salguero Engström, A. (2018). A comparison between organic and conventional olive farming in Messenia, Greece. Horticulturae, 4(3), 15

Janjhua, Y., Chaudhary, R., Mehta, P., \& Kumar, K. (2019). Determinants of farmer's attitude toward organic agriculture and barriers for converting to organic farming systems: Research insights. International Journal of Economic Plants, 6(2), 97-103.

Marsh, L., Zoumenou, V., Cotton, C., \& Hashem, F. (2017). Organic farming: knowledge, practices, and views of limited resource farmers and non-farmers on the Delmarva Peninsula. Organic agriculture, 7(2), 125-132.

McCusker, K., \& Gunaydin, S. (2015). Research using qualitative, quantitative or mixed methods and choice based on the research. Perfusion, 30(7), 537542.

Ministry of Environment, Water and Agriculture. (2019). Agriculture statistical year book. Riyadh, Saudi Arabia: Agriculture Research and Development Affairs Department of Economic Studies and Statistic, Ministry of Environment, Water and Agriculture.

Ministry of Environment, Water, \& Agriculture. (2018). National Environment Strategy. Riyadh, Kingdome of Saudi Arabia 
Creative Commons User License: CC BY-NC-ND

Abstracted by: EBSCOhost, Electronic Journals Service (EJS), Google Scholar, Journal Seek, Scientific Commons,

Food and Agricultural Organization (FAO), CABI and Scopus
Journal of Agricultural Extension

Vol. 24 (4) October, 2020

ISSN(e): 24086851; ISSN(Print); 1119944X

http://journal.aesonnigeria.org

http://www.aiol.info/index.php/iae

Email: editorinchief@aesonnigeria.org

Ministry of Environment, Water, \& Agriculture. (2019). National Agricultural Strategy. Riyadh, Kingdome of Saudi Arabia

Oyedele, G. T., Wole-Alo, F. I., Owolabi, K. E., \& Okunlola, J. O. (2018). Small-scale farmers perception on organic farming status in Ondo State,

Nigeria. American Journal of Agriculture and Forestry, 6(6), 186-190.

Pinthukas, N. (2015). Farmers' perception and adaptation in organic vegetable production for sustainable livelihood in Chiang Mai Province. Agriculture and Agricultural Science Procedia, 5, 46-51.

Ramadan, M. F. A., Abdel-Hamid, M. M. A., Altorgoman, M. M. F., AlGaramah, H. A., Alawi, M. A., Shati, A. A., Shweeta, H. A., (2020). Evaluation of pesticide residues in vegetables from the Asir Region, Saudi Arabia. Molecules, 25(1), 205. MDPI AG. Retrieved from http://dx.doi.org/10.3390/molecules25010205

Rana, S., Md. Hasan, H., Alam, M.S., Islam, M.S. (2017). Farmer attitude towards organic vegetable in Rangunia Upazila, Chittagong, Bangladesh. Journal of Biosciences Agricultural Research 14, 1151-1156.

Usman, I. S., Abdullahi, A., Qasimu, A. I., \& Adamu, T. (2016). Farmers perception on organic manure usage among arable crop farmers in Jalingo Local Government Area of Taraba State, Nigeria. Scientific Papers: Management, Economic Engineering in Agriculture \& Rural Development, 16(3), 353-359.

Thinley, P., \& Tashi, S. (2020). Farmers' perception on transitioning t. Research Journal of Agriculture and Forest, 8(1), 40-48.

Singha, A. K., Deka Bidyut, C., Bordoloi, R., \& Parisa, D. (2020). Qualifying factors influencing adoption of improved dairy farming practices by the farmers in North Eastern Region of India. Journal of Pharmacognosy and Phytochemistry, 9(3), 1559-1563.

Skaalsveen, K., Ingram, J., \& Urquhart, J. (2020). The role of farmers' social networks in the implementation of no-till farming practices. Agricultural Systems, 181, 102824.

Wayman, S., Kucek, L. K., Mirsky, S. B., Ackroyd, V., Cordeau, S., \& Ryan, M. R. (2017). Organic and conventional farmers differ in their perspectives on cover crop use and breeding. Renewable agriculture and food systems, 32(4), 376385. 